\title{
Leadership and Identity in the Catholic School: An Australian Perspective
}

\author{
William Sultmann. CFC and Raymond Brown.*
}

University of Queensland: Griffith University: Australia

\begin{abstract}
This article explores the nature of leadership as expressed in literature and workshop commentary on the identity of the Catholic school within an Australian context. Employing a qualitative methodology, data from workshops designed around school mission were compared and integrated with data from texts of selected Post Conciliar documents on the Catholic school for the purpose of gaining insights on identity. Within the identified theme of 'school' in the two bodies of narrative, the dimension of leadership was explored in its practical nature. The discussion of findings identifies the diversity of leadership practice, its dynamic relationship with the ecclesial community of the school and the desirability of an integrative image to capture this diversity and relationship. The article concludes that leadership within the Catholic school can be imagined as a response to Baptism and as such be sacramental in nature as it manifests itself as sign and instrument of the life of Christ.
\end{abstract}

Key Words: Identity, Leadership, Catholic School, Church, Sacramental Imagination

\section{Introduction}

The context and nature of Catholic school identity, together with the attendant implications for leadership, have undergone considerable change in the decades since the Second Vatican Council (1962 - 1965) and the release of such documents as Gaudium et Spes (1963) and Lumen Gentium (1964). This change is evident particularly in Post Conciliar literature on identity and is manifested in a diverse and complex set of leadership thinking and practices. While change and consolidation of an appreciation of identity can be identified, the goal of clarifying the nature of contemporary leadership which seeks to be fully integrated with school identity remains a continuing challenge (see Convey 2012).

Responses to the changed and changing practices and profiles of the Catholic School recognize the historical, pastoral contribution of Catholic schools and call for clarification and re-focusing of directions (Putney 2005). The challenge to establish clearer vision and aligned leadership in a diverse, multicultural, and multi faith context is argued to be the challenge and responsibility of all within the school. The 'way forward' suggested by 
McLaughlin (2008) is to develop a new understanding of the school community that is informed by the visions and values of participants and stakeholders and, thereafter, to build a community of shared understanding (see Cooke 1983) and witness (see Martos 2009) which invites leadership that is transformative and authentic.

Previous research into the nature of Catholic school identity (Sultmann and Brown 2011) identified a dynamic and organic interaction among five pillars; Faith, Learning, Community, Leadership and Formation. Moreover, each pillar was said to possess its own unique characteristics along with reflecting aspects of all other pillars. For example, while leadership was found to be one element of identity, this identity pillar does itself possess informative elements that load heavily into the overall nature of identity expressed across all defining characteristics. That is to say, leadership is part of identity and identity is more than leadership. What becomes important therefore is the progressive unpacking of each of the identity pillars in a fashion that elaborates on their practical and pastoral significance (see Grace 2011) and thereafter to recognize that advancing one element of identity is to inform and advance all other elements and promote identity as an overall whole.

The relationship of leadership to school vision as a key manifestation of identity is fundamental to school and organizational improvement (Kurland, Peretz, and HertzLazarowitz 2010). Kurland et al. (2010) in a large scale empirical study that examined the influence of leadership style on organizational learning, as mediated by school vision, found that leadership style was a predictor of school vision and organizational processes. That is, the more leadership is perceived by teachers to be intellectually stimulating, considerate of individual needs, inspirational, and centered on values, beliefs, and sense of mission, the more meaningful the school vision and the more school members are likely to engage in school organizational processes. As such, a focused and consistent leadership style relates to a foundational consideration of school identity as espoused through vision and mission.

A further large scale, mixed methods study designed to explore the utility of school mission statements ${ }^{1}$, Stemler, Bebell, and Sonnabend (2011), found that school leadership generally regards mission statements as important tools for shaping practice and communicating core values within the overall identity of the school. As such, school mission is important for defining the nature of community and shaping organizational structure and leadership behavior. McLaughlin (2008) makes the point that community is not a fixed or static entity that can be measured, but is more of a dynamic set of relationships that are enriched, altered, evolving and based on communication, dialogue and collaboration. The work of Akey (2006) confirms this point and extends it to include the positive effects that 
such dynamic relationships can have on student achievement. Identity in this context influences and is influenced by leadership practices.

While directions with respect to a broad strategy for nurturing a relational and supportive Catholic school identity do exist, see for example the Catholic School Identity Inventory (Hobbie, Convey, and Schuttloffel 2010), the question of identity and its relationship to leadership in an Australian context remains less clear. McLaughlin (2008) declares that what distinguishes a Catholic School from others is its focus on generating a school climate that is permeated by Gospel values. Such a view is reinforced by Episcopal declarations as to the purpose of the Catholic school being to "assist parents and parishes in their educational, evangelical and catechetical mission, as well as to help the wider community in its educational and civic service" (NSW and ACT Bishops 2007:10). What this suggests is that while identity is at the core of school life and culture, practices of leadership which nurture and align to this identity warrant inquiry and activation.

A rationale and overall framework for revisiting the relationship between identity and leadership within the Catholic School is provided by Miller (2007). Drawing upon the writing of Pope John Paul II, Miller argues that in the Australian context Catholic schools are crucial to the pastoral life of the Church. For Miller, the related tasks of strengthening Catholic identity within a faith-based community and building a culture of leadership within that community are central to the future of Catholic Education. In support of this challenge, Archbishop Miller emphasized the role of the Vatican Commission that was set up in 1965 and subsequently the development of the Sacred Congregation of Catholic Education, specifically its School Office in August 1967. It was out of this office that core documentation has been released to provide significant definition to the key elements of Catholic school identity and permit the consideration of essential organizational dimensions around which an understanding of Identity and its relationship to leadership might emerge.

In light of the dual challenges of identity clarification and associated leadership support, the scope of the research presented here builds on the work of Sultmann and Brown (2011). It does this through an examination of how leadership might be expressed within the overall framework of school identity as identified within narratives from theoretical and practical perspectives. This examination first involved an examination of leadership commentary within Post Conciliar narratives on the Catholic school and second through an examination of leadership comments from workshops designed to discuss key elements of identity. 


\section{Method}

\section{Literature Sources}

\section{Post Conciliar Narratives}

Documents chosen for analysis identified the comparative uniqueness of Catholic schools set apart from others (Hobbie, Convey, and Schuttloffel 2010). They incorporated those released by the Congregation of Catholic Education in the period 1977-2007 since the Second Vatican Council. These included: The Catholic School (1977); The Religious Dimension of Education in the Catholic School (1988); The Catholic School on the Threshold of the Third Millennium (1998), and Educating Together in Catholic Schools: A Shared Mission between Consecrated Persons and the Lay Faithful (2007).

\section{School Narratives}

A sample of eight schools was drawn from a nominated 36 school pool $^{2}$ within the context of Australia wide planning by a Religious Institute. The schools selected were reflective of the diversity of the network of schools and incorporated representation across State boundaries, enrolment profile, size, location, and socio-economic status. Workshop participants $(\mathrm{N}=96)$ responded in discussion on the nature and purpose of a Catholic School and the associated leadership expression relative to key features of identity. Participant responses were recorded and the information from each workshop was collated and transcribed for analysis.

\section{Tools of Analysis}

Leximancer and Interpretative, Phenomenological Analyses (IPA) were performed on the selected Post Conciliar documents on the Catholic school and the transcribed, collated school focus group texts to identify key concepts.

\section{Leximancer}

Leximancer is a text based research tool that analyses text and displays the extracted information in the form of a 'concept map' that displays core concepts and their relationships with other concepts (Leximancer Manual 2005). The key to Leximancer is the notion of concept: collections of words that travel throughout the text. These terms are weighted from 
how frequently they occur in sentences containing the concept compared to how frequently they occur elsewhere in a text.

Interpretative Phenomenological Analysis (IPA)

IPA attempts to 'unravel the meaning contained in accounts through a process of interpretative engagement with the text of transcripts (Smith 1997:189). Following the Leximancer analysis, a more detailed interpretative analysis was applied to the concept 'school' in each of the conciliar documents and in the collated focus group text. Three stages were applied to this analysis:

a) Data observations (generating and exploring themes, summaries, questions, use of words, metaphors etc);

b) Generating theme titles; identifying those theme titles which capture the essence of what the text displayed;

c) Connecting themes through considering their relationship and recording a superordinate theme that could be expected to emerge from the analysis.

\section{Results and Discussion}

\section{Combined Leximancer Analysis: School as Focus Concept}

The weightings of the term 'school' in each of the Conciliar documents and in the collated school focus group text showed 'school' to be the most frequently occurring term in nearly every text (see Table 1). The exception was in the text of The Religious Dimension of Education in the Catholic School (1988) where 'school' was identified as the second most dominant concept with the concept 'students' coming in at $100 \%$.

\section{Place Table 1 about here}

\section{Interpretative Phenomenological Analysis (IPA)}

Post Conciliar Documents: Applying IPA to each of the Post Conciliar documents and the collated set of focus group transcriptions allowed an overall interpretation of meaning to emerge with respect to 'school' and the dimension of leadership within it.

\section{The Catholic School}


The IPA analysis of 'school', in the text The Catholic School (1977) revealed the themes of Mission of Church, Integration, and Cultural Dialogue. Snippets of text such as 'authentic formation', 'culture and faith: faith and life', 'civic and apostolic', 'local and global', 'plurality of systems', and 'openness to change' provide the image of school as being a place of authentic formation where faith, culture and life meet as part of Church and as being a space where boundaries are recognized and negotiated for the common good. In this light, school, and by implication school leadership is imaged as being a social instrument capable of continuous renewal in the light of diverse socio-cultural contexts. The overall principles which were aligned with the identity concept of school and its resultant leadership themes could be encapsulated as being SHARED SERVICE (see Table 2).

\section{Place Table 2 about here}

\section{The Religious Dimension of Education in the Catholic School}

The IPA on the concept 'school' within The Religious Dimension of Education of the Catholic School (1988) is given in Table 3. Findings pointed to the fundamental and integral relationship between 'school' and 'students' within the life of the Catholic school. Further, the concept, school, reinforces the religious dimension within the totality of Catholic school life and culture. Through snippets of text that relate to 'religious education as being integral to all curriculum', to 'the life of Church', to 'the religious dimension of the school', and to the creation of 'a respectful and relational learning environment' emphasis is given to the themes of 'interdisciplinary relationships', 'church community', 'pastoral integration', and 'school climate'. In so doing the integrated aspects of the religious dimension in curriculum, community, pastoral care, relationships and overall culture is fore-grounded and the impact of this religious dimension is detailed enough to convey the need for the development of a cultural climate that is distinctly Catholic, yet sufficiently general to permit the pervasiveness of the dimension to apply as broadly as circumstances and vision allow. As such, the overall leadership principle which is aligned with the identity concept of school and its resultant leadership themes could be encapsulated as NURTURING AN AUTHENTIC CHRISTIAN COMMUNITY.

Place Table 3 about here

The Catholic School on the Threshold of the Third Millennium 
The IPA on The Catholic School on the Threshold of the Third Millennium (1998) (see Table 4) highlighted the significance of concepts and related themes for the identity concept 'school'. Snippets of text related to support for those most in need and the centrality of Church, fore-grounded the integrating principles for 'school' as being 'prophetic call' and 'defining features'. As such, the overall principles which were aligned with the identity concept of school and its resultant themes could be encapsulated as being PROPHETIC MISSION.

\section{Place Table 4 about here}

\section{Educating Together in Catholic Schools: A Shared Mission between Consecrated Persons and the Lay Faithful}

The IPA analysis of Educating Together in Catholic Schools: A Shared Mission between Consecrated Persons and the Lay Faithful (2007) (see Table 5) expanded upon the uniqueness of the concept 'school' by providing related themes including: through mission, conscience, relationships and climate. Overall, this core identity concept was specified in more precise terms through the attribution of integrative principles with the result for 'school' being- WITNESS.

\section{Place Table 5 about here}

The IPA analysis of the concept 'school' in the document Educating Together in Catholic Schools: A Shared Mission between Consecrated Persons and the Lay Faithful (see Table 5) identified themes of a distinctly personal and relational nature. The theme, school, while giving emphasis to mission, did so from the perspective of a living communion and with an orientation on personal attributes of conscience, relationships and climate. In this light, it is not surprising to register the integrating principle as being one which supports personal engagement and so typifies the identity characteristic of witness. Overall, the identity concept, 'school', not only defines tradition, but also suggests a movement from an institutional focus to one of an interior commitment and vocational orientation to the role of witness within the culture of the Catholic school.

\section{Analysis of Focus Groups Text}

The IPA on The Focus Group Discussion is given in Table 6. The analysis revealed that a dominant theme emerging from the text of the focus group data related to the culture of school and how it needed to reflect the history of the school and its traditions. Snippets of text relating to 'Outreach and preferential option for poor', 'History and tradition important', 
'School as beacon', 'Accessible to wide demographic', and 'School as Church' indicate a breadth of response to the question: 'Which programs structures, processes, or event in the life and work of our school are intrinsic to identity?"

Likewise, other dominant themes emerging from the text related to engagement and culture. Text relating to 'all engaged and focused', 'hands on leadership', 'creating', 'serving', and 'values based' indicate that participants, when thinking about the nature of their school, were cognizant of the importance of hands on, engaged leadership steeped in Gospel and of a type of participation that embraced values, service and leadership. As can be seen in Table 6, the IPA analysis revealed that, for these participants, the identity concept of 'school' was fostered through expressions of tradition, integration and participation. As such, the Superordinate principle that aligned with the identity concept of school and its resultant themes could be encapsulated as being shared VISION.

\section{Place Table 6 about here}

\section{General Discussion}

The research presented in this article explored the practical expression of leadership from the narratives of Post Conciliar documents and collated commentary from variable school communities within the Australian context. Drawing from the most frequently occurring concept in the narratives, that of 'school', the analysis of leadership was explored in terms of the implications posed by leadership practices being authentic to Catholic school identity.

The analysis of the concept 'school' within The Catholic School (1977) detailed the concept through the themes: mission of Church, integration and cultural dialogue. Key to this mission is the articulation of the school's specific focus as a ministry within the Church, its impact on the culture of the time and the integration of the school's activities within and beyond itself. The integration of faith, life and culture offers the essence of this mission, evidenced in the leadership practice of authentic shared service through individual and group endeavor and the promotion of culture.

The analysis of The Religious Dimension of Education in the Catholic School (1988) reinforced the religious dimension within the totality of Catholic school life and culture. Within the concept 'school', leadership emphasis is pursued through the integration of the religious dimension in curriculum, community, pastoral care and relationships. The impact of this religious dimension is seen to be manifested in the development of an authentic Christian community climate that is distinctly Catholic which in itself is inclusive and outreaching. 
The Catholic School on the Threshold of the Third Millennium (1998) highlighted the significance of the concept, 'school' through the related themes of prophetic call and defining features. Defining themes are characterized through leadership which nurtures a distinctive, open and challenging Catholic school within an equally challenging and engaging culture. It is the Catholic school's mission, and by implication the task of leadership, to support a mission that is prophetic, responsive to the signs of the times through dialogue, recognizes the relationship between formation and experience, values the ministry of teachers and is faithful to the Tradition of integrating faith with life as culture is experienced.

Within Educating Together in Catholic Schools: A Shared Mission between Consecrated Persons and the Lay Faithful (2007) the Catholic school's institutional identity is reinforced along with witness to mission supported by formation within a distinctive, relational and educative community. The challenge for leadership is to invite a baptismal commitment to Christian praxis ${ }^{3}$. School personnel are not seen in isolation from the community, which, when viewed collectively, is challenged to be inclusive, open and aware of its mission within and without. The overall themes of the document speak to the 'head, heart and hand' of identity and leadership being challenged to educate collaboratively in a Spirit of witness.

Taken as a whole the analysis of Post Conciliar documents aligns with other evidence in the field (see Convey 2012) where the identity of a Catholic school is founded on the establishment of a faith community. Within this community emphasis is given to shared service, to the nurturing of an authentic community, to a focus on mission through transmission of values, to witness in all domains of the formal and informal curriculum, and to engaging a vision which is the shared responsibility of the school community. This is consistent with the findings of Hobbie, Convey, and Schuttloffel (2010) which highlight history, tradition, and ritual ${ }^{4}$ as being important components of Catholic school identity and by implication demanding leadership attention.

The perspective on identity and leadership expressions within the focus groups underlined the importance of tradition, integration and participation. For the selected Australian school communities, tradition represents a connection that embraces a unique school story with characteristics of inclusion, outreach and a view of the school as a place of Church. Leadership expressions of this identity are evident in concepts of holism, community, relationships, and the grounded and distributive nature of leadership. The cluster of leadership expressions of school as participation also reinforces a culture of participative practices and engagement through service and outreach arising from values. The conclusion 
as to the overall nature of this unique culture of the Catholic school is expressed in the principle of leadership as a shared sacred vision.

Leadership as a shared sacred vision has implications for the future of Catholic schooling in Australia. As such, it can be assumed with confidence that future models of Catholic schooling in Australia will reflect an interpretation of the Gospel within the social, political, economic and multicultural context it serves ${ }^{5}$. Building on such core elements as 'service', 'community', 'mission' and 'witness', the 'vision' of the Catholic school in Australia will continue to evolve. Central to this will be the development of its own ecclesial identity and the connection it will possess with other ecclesial entities and the community as a whole.

The research presented here confirms that the identity of the Catholic school in Australia is argued to envision the identity of the Church overall. An implication of this is the subsequent alignment of the defining features of the Catholic school in Australia with the defining features of the Universal Church. At the same time, an opportunity exists to deepen an appreciation of the relationship between Catholic school identity and the leadership that may nurture it and so facilitate the effectiveness of Catholic schooling in Australia without compromising history, tradition, and ritual. Leadership within this framework would be energized by nurturing a servant-community, being dynamic and expressive in the nature of its witness, offering newness and growth, and typified in a climate of openness and dialogue. Moreover, the identification of an image and metaphor in support of this orientation is viewed as helpful to the practical integration of the identified components.

The Second Vatican Council provided a clear and emphatic focus on Christ as central to the life of the Church. Lumen Gentium, specifically Chapter 2, describes all within the Church, through Baptism, possessing a relationship with Christ (LG: 31) and also sharing in the saving mission of the Church (LG: 33). The Council reinforced this identity of Church when it argued: "by her relationship with Christ, the Church is a kind of Sacrament, or sign and instrument of intimate union with God and of the unity of the whole human race" (LG: $1)$.

The consideration of the Church as Sacrament signals the activity of God in the world and confirms the Church as the basic Sacrament from which the formal Sacraments flow. This position has also been advanced to include: "that the activity of Christian communities is also sacramental, even though certain actions, the sacramental liturgies, may be more formally and explicitly singled out as Sacraments" (Cooke 1983: 235). This concept of the 
universal Church and its particular communities as being imaged as a sacrament offers a 'root metaphor' - a foundation upon which the school's identity might be articulated.

The connection between the nature of Sacrament and the daily life of Christ's followers within communities such as the Catholic school is developed by Martos (2009) through a discussion of the Paschal Mystery as a model for personal morality, and the kingdom of God as a paradigm for social experience. The Paschal Mystery is described as "something that Jesus did a long time ago but that has had an effect on humanity ever since, especially on Christians" (Martos 2009: 185). In broad terms, it entails - the life, death and resurrection of the Lord - which is argued to have relevance for the community and how it celebrates the remembrance of Christ in the reality of daily experience through the action of the Spirit. The Paschal Mystery of Christ provides a framework for understanding the nature of Christ's life and how it might be manifested in the life of His disciples. It is the story of foundational relevance to the Catholic school as if offers to all who serve and relate within this environment a window into an imagination shaped by the Spirit in relation to the signs of the times.

The second link between the Sacraments and everyday discipleship is through the paradigm of the Kingdom of God: "the Church has but one sole purpose, that the Kingdom of God may come" (GS: 45). Like the Paschal Mystery, the Kingdom of God "is not about eating or drinking but about right-living, peace and joy in the Spirit of holiness" (Romans 14: 17). Given repeated attention in the documents of Vatican II and the Christian Scriptures, it is not limited to the ministry of the ordained; but given emphasis within "the special vocation of the laity within the 'temporal affairs' that constitute their life" (LG: 31 and 36). The Kingdom vision is intimately linked to the Paschal Mystery for it makes explicit the mind and action of Christ as life is encountered in community. It offers to the baptized a vision of how life and community might look if God were in charge.

Two integrated and foundational characteristics: being an instrument of Christ (the Living Word); and being a sign of His life (Sacred Witness); offer an image for life within the Catholic school. Within this framework, the Church (the pilgrim body of believers), and the Catholic school, proceeding from the heart of this assembly (ex corde ecclesia), are sacramental in nature as they seek to serve and make visible the compassion, mercy and forgiveness of God. In this fashion, as was the case for the early Church: Whoever came in contact with one of these believing communities was truly in contact with the presence of the risen Lord... The community was effectively acting as a Sacrament of the risen Christ... It 
was the entire existence and activity of the community that was sacramental (Cooke 1983: 72).

\section{Notes}

${ }^{1}$ See also Grace (1998 117-127) on the importance of school mission statements.

${ }^{2}$ At the time of this study, the nominated pool of schools consisted of 36 religious order owned schools enrolling over 25,000 students throughout all the states of Australia.

${ }^{3}$ We share Groome's (2006) understanding of 'Christian praxis' to be a process of reflection which brings faith to life and life to faith. Groome uses the term 'praxis' as synonymous with reflection, and argues that the integration is evidenced in outcomes which impact the 'head, heart and hand' of being. In this way, Catholic Christian faith might become the essence of personal identity and permit the expression of Baptism in all aspects of Christian living.

${ }^{4}$ Hobbie, Convey, and Schuttloffel (2010) highlight the Catholic school as being one in which the Catholic faith, morals, and practices are evident. We agree with Convey (2012) that an important element of these practices is the celebration of rituals, namely, prayer, liturgy and sacraments.

${ }^{5}$ In terms of the Australian context this confidence is boosted by the work of authors such as Kevin Treston 1997 -Ethos and identity: foundational concerns for Catholic schools and Denis McLaughlin 2008 - A School of the Human Person and for the Human Person.

\section{Notes on Contributors}

Dr William Sultmann is Adjunct Professor, University of Queensland and Director of Mission, Oceania Province of the Congregation of Christian Brothers.

wfsultmann@edmundrice.org

Dr Raymond Brown is Associate Professor in the School of Education,

Griffith University, Australia

Ray.brown@griffith.edu.au

\section{References}

Akey, Theresa M. 2006. "School Context, Student Attitudes and Behavior, and Academic Achievement: An Exploratory Analysis." MDRC (2006).

Bishops of NSW and the ACT. 2007. Catholic Schools at a Crossroads. Pastoral Letter. Bishops of NSW and ACT in association with Catholic Education Office, Sydney.

Congregation for Catholic Education. 1976. The Catholic School. Homebush, NSW: St Paul Publications.

Congregation for Catholic Education. 1988. The Religious Dimension of Education in a Catholic School: Guidelines for Reflection and Renewal. Homebush, NSW: St Paul Publications. 
Congregation for Catholic Education. 1998. The Catholic School on the Threshold of the Third Millennium. Homebush, NSW: St Paul Publications.

Congregation for Catholic Education. 2007. Educating together in Catholic Schools: a shared mission between consecrated persons and the lay faithful. St Paul's, Sydney.

Convey, John J. 2012. "Perceptions of Catholic identity: Views of Catholic school administrators and teachers." Journal of Catholic Education 16 (1): 187-214.

Cooke, Bernard. 1983. "Sacraments and Sacramentality (Mystic, CT: Twenty." Third Publications 54: 17-18.

Fisher, A. 2006. "Purposes of Catholic secondary schools today." Address to the Catholic Secondary Schools Association, Sydney 31 (2006).

Gentium, Lumen. 1964. "Dogmatic constitution on the Church." Pope Paul VI.

Good News Bible. 1978. New York: American Bible Society.

Grace, Gerald. 1998. 'Realizing the Mission: Catholic Approaches to School Effectiveness' in R. Slee et al, School Effectiveness for Whom? London, Falmer Press.

Grace, Gerald. 2011. "Editorial.” International Studies in Catholic Education, 3 (1): 1-2.

Groome, T. 2006. 'Bringing life to faith and faith to life: for a shared Christian praxis approach and against a detractor'. Compass 40: 17-24.

Hart, Daniel, Thomas M. Donnelly, James Youniss, and Robert Atkins. 2007. "High school community service as a predictor of adult voting and volunteering." American Educational Research Journal 44 (1): 197-219.

Hobbie, M., J. J. Convey, and M. J. Schuttloffel. 2010. "The impact of Catholic school identity and organizational leadership on the vitality of Catholic elementary schools." Catholic Education: A Journal of Inquiry and Practice, 14 (1): 7-23.

Huffman, J. B. 2001. "The Role of Shared Values and Vision in Creating Professional Learning Communities." U.S. Department of Education: Office of Educational Research and Educational Resources Information Centre (ERIC).

John Paul II. 1989. Christifideles Laici: The Vocation and the Mission of the Lay Fiathful in the Church and in the World. Homebush, NSW: St Paul Publications.

Kurland, Hanna, Hilla Peretz, and Rachel Hertz-Lazarowitz. 2010. "Leadership style and organizational learning: the mediate effect of school vision." Journal of Educational Administration 48 (1): 7-30.

Larkin, M., S. Watts, and E. Clifton. 2006. "Giving Voice and Making Sense in Interpretative Phenomenological Analysis. Qualitative Research in Psychology, 3:102120.

Leximancer Manual (2005). http:www.leximancer.com Version 2.5.

McLaughlin, D. 2008. "A School of the Human Person and for the Human Person. British Journal of Religious Education, 22 (3): 50 - 64.

Martos, Joseph. 2009. "The Sacraments: An Interdisciplinary and Interactive Study." Collegeville, Minnesota: Liturgical Press.

Miller, J. Michael. 2006. The Holy See's teaching on Catholic schools. Sophia Inst Press.

Miller, J. Michael. 2007. "Faith Inspired Leadership: The Challenge of the Catholic Educator in the 21 Century." The Fourth International Conference of Catholic Educational Leadership. Directions for Catholic Educational Leadership in the $21^{\text {st }}$ Century: The Vision, Challenge and Reality. Sydney. Australian Catholic University.

National Planning Committee for Schools Governance. 2003. "Identifying the Characteristics of an Edmund Rice School: Report on profile school consultations." Christian Brothers Australia.

Putney, Michael. E. 2005. "The Catholic School of the Future." The Australasian Catholic Record 82 (4): 387-98. 
Smith, J.A., M. Jaman, and M. Osborn. 1999. "Doing Interpretative Phenomenological Analysis" in M. Murray and K. Chamberlain (Eds). Qualitative Health Psychology: Theories and Methods. London: Sage.

Spes, Gaudium Et. 1963. "Pastoral Constitution on the Church in the Modern World." Documents of Vatican Council II. Pope Paul VI.

Sultmann, William, and Raymond Brown. 2011. "Modelling pillars of Catholic school identity: an Australian study." International Studies in Catholic Education 3, no. 1: 7390 .

Stemler, S.E., D. Bebell, and L. Sonnabend. 2011. Using school mission statements for reflection and research. Educational Administration Quarterly, 47 (2): 383-420.

Treston, Kevin. 1997. 'Ethos and Identity: Foundational Concerns for Catholic Schools'. In R. Keane and D. Riley, (Eds). Quality Catholic Schools: Challenges for Leadership as Catholic Education Approaches the Third Millennium. Brisbane: Brisbane, Catholic Education. 
Table 1. Frequency of the term 'school' within the Post Conciliar documents and the collated school focus group text

\begin{tabular}{lcc}
\multicolumn{1}{c}{ Text Source } & $\begin{array}{c}\text { Absolute } \\
\text { Count }\end{array}$ & $\begin{array}{c}\text { Relative } \\
\text { Count (\%) }\end{array}$ \\
\hline $\begin{array}{l}\text { The Catholic School (1977) } \\
\text { The Religious Dimension of Education in the Catholic School } \\
\text { (1988) }\end{array}$ & 81 & 100 \\
The Catholic School on the Threshold of the Third Millennium \\
$\begin{array}{l}\text { (1998) } \\
\text { Educating Together in Catholic Schools: a shared mission } \\
\text { between consecrated persons and the lay faithful (2007) } \\
\text { Collated school focus group text }\end{array}$ & 34 & 100 \\
\hline
\end{tabular}


Table 2. IPA of The Catholic School (1977)

CONCEPT: SCHOOL

Stage One - Voices from Catholic in nature; Local issues impact socio cultural context; text (messages, stances, Contribution of Pontifical Congregation; Educational value as perspectives, narrative)

This stage of the IPA analysis involved a process of internal data validation.

Notably, cross-referencing was undertaken by two researchers, coding cooperatively and crosstabulating the generated text (opposite) with the original text associated with the concept 'school' from the Leximancer analysis. That is, cross-tabulation took place on data prior to the interpretive generation of themes and principles of integration. primary; 'Sacred Congregation seeks: An effective system of education at all levels which corresponds to the total educational needs of young people today in Catholic schools'; Goal: seek effective system for all; Applies holistically students, others; Service as 'civic and apostolic'; Formation of 'whole man'; Part of Church - saving mission; Gospel of Christ in cultural conditions; Plurality of systems; Cooperation in society; 'Catholic schools provide a service which is truly civic and apostolic'; Teaching of truth; Parents right to choose; Dialogue with culture; Goal of 'natural and supernatural destiny'; Service to mankind; Be wary of critique; Offers an alternative; Be careful of 'social discrimination'; Rapidly changing society; Pastoral activity in State schools; Special mission in being a 'good school'; Personal contacts and values in life; Real life awareness; Review process of formation; Draw out ethics, nurture spiritual dynamism; Authentic formational place; People - inner directed by conscience; Vatican II: unites teaching and RE to profession; Laity: invited to cooperate with RE instruction; Culture and faith: faith and living integration; Distinctive Christian environment; Parent support of school efforts.

Stage Two (Themes and Mission of Church: Evangelization; Culture and faith: faith Indicators) and life; Authentic - whole 'man' formation; Natural, supernatural destiny; Authentic formation; Distinctive environment

Integration: Civic and apostolic; Local and global; Natural and supernatural; Beliefs and values; Lay, religious, clerical

Cultural Dialogue: Recognition by society; Place in society; Good school; Service of community; Alternative; Institution within society; Open to critique; Plurality of systems; Openness to change; Renewal

Stage Three (Overarching 1. Mission of Church: A place of authentic formation where narrative) faith and culture, faith and life meet within the mission of the Church.

2. Integration: A space where boundaries are recognized and negotiated for common good.

3. Cultural Dialogue: An effective social instrument, continuously renewing in light of diverse socio-cultural context. 
Table 3. IPA of The Religious Dimension of Education in the Catholic School (1988)

\section{CONCEPT: SCHOOL}

Stage One - Voices from text (messages, stances, perspectives, narrative)

Stage Two (Themes and Indicators)

Stage Three (Overarching narrative)
Science and technology engagement; Address holism in curriculum; Overall religious perspective; Interdisciplinary approaches; 'At the same time it must fulfill its own educational goals by blending human culture with the message of salvation into a coordinated program; it must help each of the students to actually become the 'new creature' that each one is potentially, and at the same time prepare them for the responsibilities of an adult member of society'; Primary focus and integration of RE; Catechesis as different to RE; RE as special focus of administrators; Measure progress of RE; 'Since its educational goals are rooted in Christian principles, the school as a whole is inserted into the evangelical function of the Church. It assists in and promotes faith education'; School climate - warm and friendly; 'Parents are central figures, since they are the natural and irreplaceable agents in the education of their children ....... Partnership between a Catholic school and the families of the students must continue and be strengthened'; Formation of lay people; Student cooperation; Respect of students; Cross curricula motivation; Horizontal and vertical dimensions (reality and spirit); Rationale for further research; Administrative imperatives; 'Everything possible must be done to ensure that Catholic schools have adequately trained religion teachers; it is a vital necessity and a legitimate expectation'; Baptism as central to new life; Membership through Baptism.

Interdisciplinary Relationships: Methods; Knowledge; Integration of RE; Catechesis as different to RE; Religious values and motivations in all subject areas.

Church Community: Place of catechesis; Handing on of Gospel; School as part of Church evangelization; Baptism as central: distinct form of membership

Personal Integration: Coordinate RE with parish, youth, family; Witness of teachers as RE specialists; Quality of formation for lay teachers; Horizontal and vertical aspects of school life; Administrators to raise awareness.

School Climate: Warm, friendly, empathetic; Helpful teachers; Respectful teachers of individuals; Flow of grace in processes. Interdisciplinary: A view of religious education as integral to all curriculum areas and the hidden curriculum of the school. Church Community: School as integral to the life of the Church within the parish and diocese.

Personal Integration: Nurturing religious dimension of school through formation and interpretation of life as 'mystery'.

School Climate: Creation of a respectful and relational environment for learning. 


\begin{tabular}{lllll}
\hline $\begin{array}{l}\text { SUPERORDINATE } \\
\text { PRINCIPLE }\end{array}$ & $\begin{array}{l}\text { NURTURING } \\
\text { COMMUNITY }\end{array}$ & AN & AUTHENTIC & CHRISTIAN \\
\hline
\end{tabular}

Table 4. IPA of The Catholic School on the Threshold of the Third Millennium (1998)

\section{CONCEPT: SCHOOL}

Stage One - Voices from Education conceptualizes child as part of wider environments; text (messages, stances, Call for new educational models; Call for courageous renewal; perspectives, narrative) Call to be effective and convincing; Focus on 'fundamental characteristics' to be effective; Historical support to young who experience difficulties; Concern for students who cannot afford Catholic schooling: 'school for all'; School to help young find a place in society 'characterized by technical and scientific skill'; Fundamental focus: still on Christian formation but also 'school for human person' - development of whole person, human values finding fulfillment in Christ; 'The Catholic school should be able to offer young people the means to acquire the knowledge they need to find a place in society which is strongly characterized by technical and scientific skill'; Educational project inspired by Gospel; 'The Catholic school sets out to be a school for the human person and of human persons'; Increase awareness of ecclesial identity: Instrument of Church, Evangelizing mission, Pastoral ministry, Teaching institution, Experience of Church, Christian community, Religious Institute charism; Sensitize parish and diocese to support; Goal is: synthesis of culture and faith; Curriculum is formation: subjects offer knowledge and values; Special attention to 'weakest in society - needs of socially and economically disadvantaged'; Partnership with other institutions; Be a leader as an ecclesial community; Responsibility for creating new Catholic school rests with teachers, as individuals and as a community.

Stage Two (Themes and Prophetic Call: Renewal of educational models; Attention to Indicators) most needs (socially, financially); New world (science and technology).

Defining Features: Fulfillment in Christ; Ecclesial community; Instrument of Church; Experience of Church; Christian community of staff; RI charism; Teaching institution; Parish and diocesan connection.

Stage Three (Overarching narrative) Prophetic Call: To support those in most need within a new world.

Defining Features: Centrality of being and building Church.

SUPERORDINATE MISSION PRINCIPLE 
Table 5. IPA of Educating Together in the Catholic School (2007)

CONCEPT: SCHOOL

Stage One - Voices from Aspire to be Christian community; Challenges of new times; text (messages, stances, 'Communion is essence of Church' the 'home and school of perspectives, narrative)

Stage Two (Themes and Mission: Service; Shared values; To build communion; To be Indicators) communion; Communion of life, common belonging to Christ; Communities of dialogue; Discernment and accompaniment as 'ecclesial experience'; Educating 'in and for communion'; Educational commitment according to logic of assistance; Educational service enlivened by Gospel; Express spirituality as an attitude of evangelical fraternity; Focus on formation requirements of society; Integrate human subjects; Interpersonal relations 'form and verify the school community'; Lay - 'active vocational conscience'; Lay called to live in faith a secular vocation for 'integral formation of human person'; Liberty and charity - atmosphere based on Gospels; Linkages to other Roman documents; Mission assumes special meaning through promotion of 'spirituality of communion' - prospect of 21st century; Norms, drives, goals from evangelical values; Nourished by 'living relationship with Christ and with the Church' makes school an authentic ecclesial experience; Pastoral emphasis to build unity; Project is convincing only if witnessed to Christ as model; 'Real' educational community founded on shared values; Reflective of Trinitarian communion; School 'for the person and of persons'; School as an expression of Church, of diversity and complementarity; School is 'communitarian, organic and intentional'; School referred to as a world; 'Solid professional formation' is key; 'Spirituality of communion' is fundamental point of reference for shared mission; Teacher represents a 'synthesis of faith, culture and life'

$\begin{array}{ll}\text { Indicators) } & \text { Conscience: Attitude (spirituality); Commitment; 'Logic of } \\ & \text { assistance'; Spirituality of communion; Active vocational } \\ & \text { conscience; } \\ & \text { Relationships: Christ centered; REC/education community; } \\ & \text { Discernment and accompaniment; Living relationships. } \\ & \text { Climate: Communion of life; Norms, drives, goals; Dynamic } \\ & \text { and intentional; Aspirational. } \\ \text { Mission: Engagement of service through a synthesis of shared } & \text { values and lived communion in life and culture. } \\ \text { Stage Three (Overarching } & \text { Conscience: The intentional creation of a spiritual communion } \\ \text { narrative) } & \text { with Christ guided by a goal of assistance. } \\ & \text { Relationships: Living relationships characterized by } \\ \text { discernment and accompaniment with and for Christ. } & \text { Climate: An aspirational community of life based on norms } \\ \text { and goals. } & \text { WITNESS } \\ \text { PRINCIPLE } & \end{array}$


Table 6. IPA of focus group collated text

\section{CONCEPT - SCHOOL}

Stage One - Voices School with an authority; Feed kids before; Attitude of staff from text (messages, positive culture; United staff; Design allows accessibility; stances, perspectives, Community support; Student leadership; Long and changing narrative) history; Students design of learning/active participants; Structures focused on student support; Post school connections; Student mix ('rich and poor'); Ancillary staff involvement; Leadership - servant leadership; Social justice values; Student choice in learning; School as beacon (hope) to community; Environment softened to support learning; Vulnerability of students monitored; Within school transition; Old collegian events; Profile in community; Students as advocates; Gospel values and relationships; Pride of students in school; Fullness of life emphases; Personal and spiritual growth; Connectivity of relationships; Student 'buddy' systems; Mixed staff - gender balance; High expectations of students - families; OId collegian connection to school and one another; Hands on Principal leadership; Basics done very well; Clarity and depth of vision; Accessible to wide demographic; Orientation to the school welcoming; Teachers role as vocational; Indigenous outreach; Student leadership opportunities; Assistance to struggling students; At risk students - early recognition; School identity emphasized through ritual events; Achievable outcomes for marginalized; Leadership team presence; School as Church for many students; Strong promotion of integration

Stage Two (Themes and Tradition: Outreach and preferential option for poor; History and Indicators) tradition important; School as beacon; Accessible to wide demographic; School as Church

Engagement: Meaning of charism; Integration of activities; All engaged and focused; Hands on leadership

Culture: Participating; Creating; Serving; Values based; Monitoring; Pride; Fullness of life; Continuing engagement; Leadership.

Stage Three

1. Tradition of school: foundations in history with hallmarks of (Overarching narrative) inclusion and as a place of Church.

2. Engagement: a hands on, engaged leadership steeped in Gospel and charism.

3. Culture: participation in fullness of life with expectations of engagement through values, service and leadership influence on a continuing basis.

SUPERORDINATE VISION PRINCIPLE 